\title{
KĀ IZTURĒT UBER TESTU. EST SECINĀJUMI LIETĀ C-62/19 STAR TAXI APP
}

\section{HOW TO PASS THE UBER TEST. CJEU CONCLUSIONS IN THE CASE C-62/19 STAR TAXI APP}

\author{
Vija Kalniņa, Mg. iur. \\ Latvijas Universitātes Juridiskās fakultātes doktorante
}

\begin{abstract}
Summary
The controversial Uber test has been applied once again. The CJEU judgment in the case C62/19 Star Taxi App acknowledges that the test is applicable and correct in its current form and no changes or improvements can be expected at least for now. In the meantime, the judgment gives one more example on how the Uber test can be executed and what are the preconditions for passing this test successfully. However, one of the most significant aspects that could affect the outcome of this test, that is, whether the factors of the Uber test are cumulative or alternative, remains unclear.

Atslēgvārdi: informācijas sabiedrības pakalpojumi, Uber tests, transporta pakalpojumi, Direktiva 2000/31.
\end{abstract}

Keywords: information society services, Uber test, transportation services, Directive $2000 / 31$.

\section{Ievads}

2020. gada 3. decembrī Eiropas Savienības Tiesa (turpmāk - EST) pasludināja spriedumu lietā C-62/19 Star Taxi App, atzīstot Star Taxi App sniegtos pakalpojumus par informācijas sabiedrības pakalpojumiem. Star Taxi App ir trešais pakalpojumu sniedzējs, kura pakalpojumiem ticis piemērots Uber tests, kas pirmo reizi tika nostiprināts EST spriedumā lietā C-434/15 Asociación Profesional Elite Taxi (turpmāk - Elite Taxi). Atšķirībā no pārējiem pakalpojumiem, kuriem līdz šim piemērots Uber tests - Uber un Airbnb pakalpojumi -, Star Taxi App nav līdzdalības ekonomikas (arī sadarbỉbas vai sadarbīgās ekonomikas) ${ }^{1}$ pakalpojumu sniedzējs. Proti, šì platforma nenodrošina pakalpojumu sniegšanas iespējas personām, kuras nav profesionālas pakalpojumu sniedzējas un dalās ar saviem brīvajiem resursiem. Tomēr jāatzīmē, ka EST arī nav devusi norādes, ka Uber tests ir attiecināms tikai uz līdzdalības ekonomikas pakalpojumiem, un, ievērojot to, ka tā šo

${ }^{1}$ Sīkāk par šiem jēdzieniem sk.: Kalniņa V. Tehnologijas, kas maina ekonomiku un tiesisko attiecību modeluus. Jurista Vārds, 02.07.2019., Nr. 26 (1084). 
testu ieviesa, pamatojoties uz ǵenerāladvokāta Maceja Špunara (Maicej Szpunar) secinājumiem, var droši apgalvot, ka tam Uber tests ir piemērojams plašākam lokam pakalpojumu. ${ }^{2}$ Spriedums lietā C-62/19 Star Taxi App to apstiprina.

Šā raksta mērķis ir analizēt EST veikto Star Taxi App pakalpojumu izvērtējumu un salīdzināt šajā lietā izdarītos secinājumus ar secinājumiem lietā C-434/15 Elite Taxi un lietā C-390/18 Airbnb Ireland, skaidrojot priekšnoteikumus Uber testa sekmīgai izturēšanai.

\section{Lietas C-62/19 Star Taxi App apstākḷi un prejudiciālie jautājumi}

Lietā tiek aplūkots pakalpojums - Star Taxi App lietotne, kas bez starpniecības nodrošina taksometru pakalpojumu izmantotāju un taksometru vadītāju savienošanu. Persona, kura vēlas pārvietoties pilsētā, šajā lietotnē var saṇemt pieejamo taksometra pakalpojumu sniedzēju sarakstu ar informāciju par piedāvātajiem tarifiem, ko nosaka paši taksometru vadìtāji, komentārus un novērtējumus no citiem klientiem. Persona var pati izvēlēties pakalpojuma sniedzēju, saglabājot iespēju no pakalpojuma atteikties. Samaksu par taksometra pakalpojumu persona veic vadītājam tieši. Svarīgi, ka Star Taxi App par pakalpojumu sniegšanu slēdz līgumus ar profesionāliem taksometru vadìtajiem, kuri ir ieguvuši tiesības veikt pārvadājumus ar taksometru, neveicot nekādu citu papildu atlasi. Saskaṇā ar noslēgtajiem līgumiem vadītāju rīcībā Star Taxi App nodod lietotni Star Taxi - vadītājs, viedtālruni, kurā instalēta šī lietotne, kā arī SIM karti ar ierobežotu datu apjoma limitu, par to no vadītājiem iekasējot mēneša abonentmaksu. Star Taxi App nav izveidota sistēma transportlīdzekḷu un vadītāju snieguma kvalitātes, ne arī šo vadītāju izturēšanās kontrolei. ${ }^{3}$

2017. gada 19. decembrī tika grozìts likums, kas nosaka pārvadājumu ar taksometriem noteikumus Bukarestēe, paredzot, ka tikai licencētas taksometru rezervēšanas centrāles drīkst nodrošināt klientiem iespēju pasūtīt taksometra pakalpojumus pa tālruni vai ar citiem līdzekḷiem, tostarp izmantojot internetam pieslēgtas lietotnes. Tā kā Star Taxi App nebija saṇēmis licenci, tam tika piemērots naudas sods aptuveni 925 eiro apmērā. Star Taxi App minēto naudas sodu apstrīdēja, uzskatot, ka tas sniedz informācijas sabiedrības pakalpojumus un tāpēc saskaṇā ar Direktīvas 2000/31 4 . pantu kā tā darbības priekšnoteikumu nedrīkst izvirzìt prasību saņemt iepriekšeju atḷauju. ${ }^{5}$ Bukarestes apgabaltiesai, kura izskatīja Star Taxi App sūdzību, radās šaubas par tā sniegto pakalpojumu klasifikāciju, un tā vērsās EST ar četriem prejudiciālajiem jautājumiem. Pirmais jautājums bija par to, vai Star Taxi App sniegtie pakalpojumi ir klasificējami par informācijas sabiedrības pakalpojumiem, savukārt pārējie jautājumi jau bija par Eiropas Savienības normatīvajos aktos paredzēto pakalpojumu sniegšanas brīvības garantiju saturu

${ }^{2}$ Ģ̣enerāladvokāta Maceja Špunara 11.05.2017. secinājumi lietā C-434/15 Asociación Profesional Elite Taxi, 42. punkts.

${ }^{3}$ Lietas apstākḷus sk.: EST 03.12.2020. spriedumā lietā C-62/19 Star Taxi App, 25.-28. punkts.

${ }^{4}$ Eiropas Parlamenta un Padomes Direktīva 2000/31 par dažiem informācijas sabiedrības pakalpojumu tiesiskiem aspektiem, jo īpaši elektronisko tirdzniecību, iekšējā tirgū (Direktīiva par elektronisko tirdzniecỉbu). OV L 178, 17.07.2000., 1.-16. lpp. Pieņemta 08.06.2000. [08.06.2000. red.].

5 Lietas apstākḷus sk.: EST 03.12.2020. spriedumā lietā C-62/19 Star Taxi App, 29.-33. punkts. 
un dalībvalstu pienākumiem. ${ }^{6}$ Šā raksta vajadzībām turpmāk aplūkoti tikai EST secinājumi par Star Taxi App sniegto pakalpojumu klasifikāciju.

\section{Star Taxi App pakalpojumu izvērtējums}

EST Star Taxi App sniegtos pakalpojumus vērtēja pēc tādas pašas shēmas, kādu tā ir piemērojusi, vērtējot Uber un Airbnb pakalpojumus. Proti, EST vispirms pārbaudīja, vai attiecīgais pakalpojums atbilst prasībām, kas izriet no informācijas sabiedrības pakalpojumu definīcijas, kura nostiprināta Direktīvas 2015/15357 1. panta 1. punkta b) apakšpunktā (iepriekš Direktīvas 98/34 ${ }^{8} 1$. panta 2. punktā). Konstatējot, ka Star Taxi App pakalpojumi atbilst šìm prasībām, EST piemēroja Uber testu.

Pārbaudi pēc Direktīvas 2015/1535 1. panta 1. punkta b) apakšpunkta Star Taxi App pakalpojumi izgāja pārliecinoši. EST atzina, ka Star Taxi App pakalpojums atbilst visiem četriem normā nostiprinātajiem informācijas sabiedrības pakalpojuma priekšnoteikumiem un principā būtu atzīstams par informācijas sabiedrības pakalpojumu Direktīvas 2000/31 izpratnē. ${ }^{9}$ Autores ieskatā, EST secinājumi šajā daḷā nav pārsteidzoši. Gadijjumos, kad ir runa par interneta platformu klasificēšanu par informācijas sabiedrības pakalpojumiem, šādas platformas gandrīz vienmēr sekmīgi iziet šo pārbaudi. ${ }^{10}$

Lietās C-434/15 Elite Taxi un C-390/18 Airbnb Ireland EST ir secinājusi, ka ir iespējama situācija, ka starpniecības pakalpojums, kurš atbilst visiem Direktīvas 2015/1535 1. panta 1. punkta b) apakšpunktā noteiktajiem kritērijiem, var būt neatņemama sastāvdaḷa tādam visaptverošam pakalpojumam, kura galvenais elements ir juridiski kā citādi kvalificējams pakalpojums. Šādā gadījumā darbībām tiešsaistē nebūtu autonomas ekonomikas vērtības un to aizsardzība nebūtu efektīva Direktìvas 2000/31 mērķu sasniegšanai, ${ }^{11}$ tāpēc tas nevar tikt atzìts par informācijas sabiedrības pakalpojumu, bet gan par pakalpojumu jomā, kurā ietilpst visaptverošais pakalpojums. ${ }^{12}$ Lai noskaidrotu, vai tas nav attiecināms arī uz Star Taxi App, EST piemēroja Uber testu.

Lietā C-434/15 Elite Taxi nostiprinātais Uber tests paredz, ka situācijās, kur pastāv iespējama starpnieku pakalpojuma cieša saikne ar vispārējo pakalpojumu,

${ }^{6}$ Lietas apstākḷus sk.: EST 03.12.2020. spriedumā lietā C-62/19 Star Taxi App, 34.-36. punkts.

7 Eiropas Parlamenta un Padomes 09.09.2015. Direktivva 2015/1535, ar ko nosaka informācijas sniegšanas kārtību tehnisko noteikumu un informācijas sabiedrības pakalpojumu noteikumu jomā. OV L 241, 17.09.2015., 1.-15. lpp. Pieņemta 09.09.2015. [09.09.2015. red.]. Šis normatīvais akts vienīgais definē jēdzienu "informācijas sabiedrības pakalpojumi", un Direktīvas 2000/31 2. panta a) punktā ir ietverta atsauce uz šo definīciju.

8 Eiropas Parlamenta un Padomes Direktīva 98/24/EK, ar ko nosaka informācijas sniegšanas kārtību tehnisko standartu un noteikumu jomā. OV L 204, 21.07.1998., 37.-48. lpp. Pieņemta 22.06.1998. [26.07.2019. red.].

9 EST 03.12.2020. spriedums lietā C-62/19 Star Taxi App, 48. punkts.

10 Sk., piemēram, EST 16.02.2012. spriedums lietā C-360/10 SABAM, 16.-18. un 27. punkts, EST 12.07.2011. spriedums lietā C-324/09 L'Oreal u. c., 109. punkts. Sk. arī generāladvokāta Nīlo Jēskinena 09.12.2010. secinājumu lietā C-324/09 L'Oreal u. c.. 134. punktu.

${ }^{11}$ G̦enerāladvokāta Maceja Špunara 11.05.2017. secinājumi lietā C-434/15 Asociación Profesional Elite Taxi, 32. punkts.

12 EST 19.12.2019. spriedums lietā C-390/18 Airbnb Ireland, 50. punkts; EST 20.12.2017. spriedums lietā C-434/15 Asociación Profesional Elite Taxi, 40. punkts. 
kura sniegšana tiek organizēta ar starpnieku pakalpojuma palīdzību, papildus pārbaudāmi šādi apstākḷi:

1) vai ar aplikācijas (platformas) palīdzību tiek veidots transporta (vai citu) pakalpojumu tirgus (piedāvājums); ${ }^{13}$

2) vai aplikācijai (platformai) ir noteicoša ietekme uz attiecīgā pakalpojuma sniegšanas kārtību, tostarp, vai tā nosaka galvenos pakalpojuma aspektus. $^{14}$

Lietā C-62/19 Star Taxi App EST, pirmkārt, konstatēja, ka aplūkojamais pakalpojums ir vienīgi personu, kuras vēlas pārvietoties pilsētā, savienošana tikai ar licencētiem taksometru vadìtājiem, kuri jau ir tirgus dalïbnieki un kuriem minētais starpniecības pakalpojums ir tikai viens no veidiem, kā iegūt klientus, turklāt tiem nav nekāda pienākuma to izmantot. ${ }^{15}$ Attiecīgi netika konstatēts, ka Star Taxi App veidotu transporta pārvadājumu pakalpojumu tirgu.

Otrkārt, EST nekonstatēja arī Star Taxi App noteicošu ietekmi uz attiecīgā pakalpojuma sniegšanas kārtību, jo pakalpojumu sniedzējs neorganizē pārvadājumu veikšanu, tas neizvēlas taksometru vadītājus, nedz arī nosaka vai iekasē brauciena maksu, nedz kontrolē transportlīdzekḷu, kā arī to vadìtāju izturēšanos. ${ }^{16}$

Tā kā atbilde uz abiem Uber testa jautājumiem ir noliedzoša, EST atzina, ka Star Taxi App sniegtais starpniecības pakalpojums nevar tikt uzskatīts par tāda vispārējā pakalpojuma neatņemamu sastāvdaḷu, kura galvenais elements ir pārvadājumu pakalpojums, un līdz ar to tas ir kvalificējams par informācijas sabiedrības pakalpojumu. ${ }^{17}$

Šis EST secinājums nozìmē to, ka Star Taxi App var paļauties uz visplašākajām pakalpojumu sniegšanas brīvības garantijām, kas paredzētas informācijas sabiedrības pakalpojumu sniedzējiem - gan uz garantijām, kas izriet no LESD 56. un 57. panta un Pakalpojumu direktīvas, ${ }^{18}$ gan arī uz garantijām, kas noteiktas Direktīvā 2000/31. Papildus jāatgādina, ka gadījumā, ja secinājums būtu pretējs, kā tas bija Uber gadījumā, Star Taxi App sniegtos pakalpojumus atzīstot par pakalpojumiem transporta jomā, tas nevarētu atsaukties ne uz vienām pakalpojumu sniegšanas brīvības garantijām, jo saskaṇā ar LESD 58. un 90. pantu transporta pakalpojumi ir izslēgti no pakalpojumu sniegšanas brīvības piemērošanas sfēras.

\section{Secinājumi, kas izriet no sprieduma lietā C-62/19 Star Taxi App}

Pēc EST sprieduma lietā C-434/15 Elite Taxi Uber un citu līdzīgu pakalpojumu (jo īpaši transporta pakalpojumu) sniedzējiem aktualizējās jautājums par to, kā izpaustos pakalpojumi, kuri var iziet Uber testu un palauties uz pakalpojumu sniegšanas brīvības garantijām, kas paredzētas informācijas sabiedrības pakalpojumu sniedzējiem. Tāpat arī tika izteikta kritika par to, ka Uber tests,

${ }^{13}$ EST 20.12.2017. spriedums lietā C-434/15 Asociación Profesional Elite Taxi, 38. punkts.

14 Turpat, 39. punkts.

15 EST 03.12.2020. spriedums lietā C-62/19 Star Taxi App, 52. punkts.

16 Turpat, 53. punkts.

17 Turpat, 54. punkts.

18 Eiropas Parlamenta un Padomes Direktīva 2006/123 par pakalpojumiem iekšējā tirgū. OV L 376, 27.12.2006., 36.-68. lpp. Piencemta 12.12.2006. [12.12.2006. red.]. 
iespējams, būtu precizējams, jo īpaši tāpēc, ka EST judikatūrā nav atrodams apstiprinājums un tiesību zinātniekiem nav vienprātības par to, vai Uber testa kritēriji ir kumulatīvi vai alternatīvi. ${ }^{19}$ Papildus tam pēc EST sprieduma lietā C-390/18 Airbnb Ireland radās jautājumi par to, kādi elementi veido Uber testu un kā tie būtu novērtējami, šim spriedumam radot iespaidu, ka galvenie apstākḷi, kas jākonstatē Uber testā, ir tikai vispārīgā pakalpojuma tirgus veidošana un ietekme uz pakalpojuma cenas noteikšanu, savukārt pārējiem apstākliiem ir sekundāra nozīme. ${ }^{20}$

EST spriedums lietā C-62/19 Star Taxi App minētajos jautājumos vieš zināmu skaidrību. Pirmkārt, tas apstiprināja Uber testa piemērošanu un formu (noskaidrojamie jautājumi ir tieši tādi paši kā lietā C-434/15 Elite Taxi). Otrkārt, EST spriedums lietā C-62/19 Star Taxi App ilustrē, kas ir Uber pakalpojumiem pretējais, proti, tāds pakalpojums, kas sekmīgi iziet Uber testu. Labākai uzskatāmībai autore tabulā apkopojusi, kādi apstākḷi Star Taxi App un Uber gadījumā vērtēti Uber testā un ietekmējuši EST secinājumus par testa iznākumu.

Tabula. Uber testa kritēriju izvērtējums Star Taxi App un Uber gadījumā

\begin{tabular}{|c|c|c|}
\hline Uber tests & Star Taxi App & Uber \\
\hline $\begin{array}{l}\text { Transporta } \\
\text { pakalpoju- } \\
\text { mu tirgus } \\
\text { izveide }\end{array}$ & $\begin{array}{l}\text { Lietotāji, transporta pakalpojuma } \\
\text { sniedzēji - licencēti taksometru va- } \\
\text { dītāji, kuri jau ir tirgus dalībnieki un } \\
\text { kuriem starpniecības pakalpojums ir } \\
\text { tikai viens no veidiem, kā iegūt klien- } \\
\text { tus, un kuriem nav nekāda pienāku- } \\
\text { ma to izmantot }\end{array}$ & $\begin{array}{l}\text { Lietotāji, transporta pakalpojuma } \\
\text { sniedzēji - autovadītāji, kuri nav } \\
\text { profesionāl̦i, iepriekš nav bijuši tir- } \\
\text { gus dalībnieki un kuri pārvadāju- } \\
\text { ma pakalpojumus nevar sniegt bez } \\
\text { starpniecības pakalpojuma }\end{array}$ \\
\hline \multirow{4}{*}{$\begin{array}{l}\text { Noteicoša } \\
\text { ietekme uz } \\
\text { vispārējo } \\
\text { pakalpoju- } \\
\text { mu }\end{array}$} & Neizvēlās taksometru vadītājus & $\begin{array}{l}\text { Izvirza prasības autovadìtājiem, kuri } \\
\text { var sniegt pakalpojumu }\end{array}$ \\
\hline & $\begin{array}{l}\text { Nenosaka un neiekasē brauciena } \\
\text { maksu (samaksa notiek pa tiešo tak- } \\
\text { sometra vadītājam) }\end{array}$ & $\begin{array}{l}\text { Nosaka vismaz augstāko brauciena } \\
\text { cenu un organizē pakalpojumu ap- } \\
\text { maksas kārtību, iekasējot maksu no } \\
\text { klientiem un ieturot savu daļu pirms } \\
\text { atlīdzības pārskaitīšanas autovadītā- } \\
\text { jiem }\end{array}$ \\
\hline & $\begin{array}{l}\text { Nekontrolē transportlīdzekḷu kvali- } \\
\text { tāti }\end{array}$ & Izvirza prasības transportlīdzekḷiem \\
\hline & Nekontrolē vadītāju izturēšanos & $\begin{array}{l}\text { Izveido un uztur autovadītāju no- } \\
\text { vērtēšanas sistēmu, kur novērtējums } \\
\text { var būt par pamatu darbíbas ierobe- } \\
\text { žošanai vai izslēgšanai no platformas }\end{array}$ \\
\hline
\end{tabular}

19 Par Uber testa kritērijiem kā kumulatīviem sk., piemēram, Ferro M. S. Uber Court: a look at recent sharing economy cases before the CJEU. UNIO - EU Law Journal, Vol. 5, No. 1, January 2019, p. 73. Par Uber testa kritērijiem kā alternatīviem sk., piemēram, Menegus G. "Uber Test” Revised? Remarks on Opinion of AG Szpunar in Case Airbnb Ireland. European Papers, 15.07.2019., Vol. 4, No. 2, p. 607; Ducato R. ECJ, Case C-434/15, Asociación Profesional Elite Taxi: preliminary notes. Pieejams: rosels.eu/2018/02/28/ecj-case-c434-15-asociacion-profesional-elite-taxi-preliminary-notes/ [aplūkots 14.03.2021.].

20 Sk.: Kalniņa V. Kā Airbnb atškiras no Uber. EST secinājumi lietā C-390/18 Airbnb Ireland. Grām.: Starptautisko un Eiropas Savienības tiesību piemērošana nacionālajās tiesās. Latvijas Universitātes 78. starptautiskās zinātniskās konferences rakstu krājums. Rīga: LU Akadēmiskais apgāds, 2020, 45. lpp. 
Tomēr spriedums lietā C-62/19 Star Taxi App nesniedz skaidrību jautājumā par to, vai Uber testā vērtējamie jautājumi ir kumulatīvi vai alternatīvi. Ne EST, ne arī generāladvokāts M. Špunars šo apstākli nevienā no lietām nav tieši precizējuši, tāpēc pagaidām ir iespējams tikai izteikt minējumus par Uber testa kritēriju dabu.

Par labu pieejai, ka Uber testa kritēriji varētu būt alternatīvi, norāda EST pieeja izvērtējuma veikšanā. Airbnb un Star Taxi App gadījumā EST savā analīzē neapstājās, secinot, ka platforma neveido pakalpojumu tirgu attiecīgajā jomā, bet pārbaudīja arī to, vai tai nav noteicošas ietekmes uz vispārējo pakalpojumu. Proti, Uber testa otra kritērija pārbaude norāda uz to, ka arī tikai viena kritērija izpilde varētu ietekmēt Uber testa iznākumu. Protams, apstiprinājuma šādai izpratnei nav, jo gan Star Taxi App, gan arī Airbnb gadījumā atbildes uz abiem jautājumiem ir noliedzošas, bet Uber gadijumā abas atbildes bija apstiprinošas. Līdz ar to EST judikatūrā joprojām nav nevienas lietas, kurā noteicoša ietekme uz vispārējo pakalpojumu tiktu konstatēta vai noliegta tāpēc, ka izpildīts tikai viens no Uber testa kritērijiem.

No otras puses, EST secinājumi lietā C-434/15 Elite Taxi radija iespaidu, ka Uber testa kritēriji ir kumulatīvi un viena kritērija neizpildī̌sana ļautu pakalpojumu atzīt par informācijas sabiedrības pakalpojumu. ${ }^{21}$

Jautājums par to, vai Uber testa kritēriji ir alternatīvi vai kumulatīvi, nav tikai teorētisks, jo no tā ir atkarīgas iespējas šo testu sekmīgi izturēt. Ja kritēriji ir kumulatīvi, šādu iespēju ir vairāk. Savukārt, ja kritēriji ir alternatīvi, šādas iespējas samazinās. Piemēram, Uber pakalpojumu gadījumā pirmo kritēriju principā nav iespējams mainìt, ja transporta pakalpojumu sniegšanā tiek iesaistītas personas, kas nav profesionāḷi. Bez Uber platformas personas, kas nav profesionāḷi, transporta pakalpojumus nevarētu sniegt, jo tās nevarētu atrast pakalpojumu saṇēmējus un pakalpojumu sañēmēji nevarētu atrast pakalpojumu sniedzējus. ${ }^{22}$ Attiecīgi gadijumā, ja Uber testa kritēriji ir alternatīvi, Uber, nemainot personas, kas var sniegt transporta pakalpojumus, nevarētu šo testu iziet nekādos apstākḷos. Savukārt, ja Uber testa kritēriji ir kumulatīvi, Uber pastāv iespējas manevrēt jautājumā par noteicošu ietekmi uz vispārējo pakalpojumu. Lai to konstatētu, vienlaikus jāpastāv vairākiem apstākḷiem, kas uz to norāda - prasību izvirzǐšana šoferiem, pakalpojuma cenas noteikšana un/vai iekasēšana, transportlīdzekḷu kvalitātes kontrole un vadītāju izturēšanās kontrole (tostarp ar autovadìtāju novērtēšanas sistēmām, kas var būt par pamatu darbības ierobežošanai vai izslēgšanai no platformas). Star Taxi App gadỉjumā nepastāv neviens no minētajiem apstākḷiem, tādējādi EST judikatūrā joprojām nav sniegta atbilde par to, cik daudzi no šiem apstākḷiem veidos noteicošu ietekmi uz galveno pakalpojumu, pat ja daži apstākḷi netiks konstatēti. Tomēr Star Taxi App gadījums sniedz piemērus tam, kādi tieši apstākḷi neveido noteicošu ietekmi. Tādējādi šis piemērs kopā ar lietā C-390/18 Airbnb Ireland izdarītajiem secinājumiem, ka pakalpojuma cenas noteikšana diezgan pārliecinoši norāda uz to, ka platformai ir noteicoša ietekme uz vispārējā pakalpojuma sniegšanu, var tikt izmantots kā vadlīnijas, mēǵinot rast iespēju iziet Uber testu.

${ }^{21}$ Ferro M. S. Uber Court: a look at recent sharing economy cases before the CJEU. UNIO - EU Law Journal, January 2019, Vol. 5, No. 1, p. 73.

22 Sk.: G̦enerāladvokāta Maceja Špunara 11.05.2017. secinājumi lietā C-434/15 Asociación Profesional Elite Taxi, 56. punkts. 


\section{Kopsavilkums}

1. Spriedums lietā C-62/19 Star Taxi App ir nostiprinājis Uber testu, apstiprinot, ka šis tests ir aktuāls un piemērojams gadījumos, kad pastāv šaubas, ka starpnieku pakalpojuma sniedzējam ir cieša saikne ar vispārējo pakalpojumu. Tests ir piemērojams neatkarīgi no tā, vai attiecīgais pakalpojums klasificējams kā lídzdalíbas ekonomikas pakalpojums.

2. Spriedums lietā C-62/19 Star Taxi App apstiprinājis, ka Uber tests sastāv no tādu elementu pārbaudes, kādi noteikti spriedumā lietā C-434/15 Elite Taxi, ar kuru pirmo reizi šis tests tika ieviests. Tas novērš pēc sprieduma lietā C-390/18 Airbnb Ireland radušās spekulācijas par to, ka šajā testā nozīme piešķirama tikai vienam no apstākḷiem, kas var veidot noteicošu ietekmi uz vispārējo pakalpojumu - pakalpojuma cenas noteikšanai.

3. Spriedums lietā C-62/19 Star Taxi App nesniedz skaidrību jautājumā par to, vai Uber testa kritēriji ir kumulatīvi vai alternatīvi. Ir pietiekami daudz apsvērumu par labu gan vienai, gan otrai pieejai.

4. Star Taxi App piemērs ilustrē, kā izskatās Uber pakalpojumiem pretējais jeb kas ir tie apstākḷi, kas ḷauj sekmīgi izturēt Uber testu, - tikai profesionālu pakalpojumu sniedzēju darbības organizēšana, platformas lietotāju neizvēlēšanās, pakalpojuma maksas nenoteikšana un neiekasēšana, transportlīdzekḷu kvalitātes un vadītāju izturēěanās nekontrolēšana. Tomēr to, cik daudzi no minētajiem apstākḷiem būtu pietiekami Uber testa sekmīgai iziešanai, no EST judikatūras neizriet un ir atkarīgs no tā, vai Uber testa kritēriji ir kumulatīivi vai alternativi. 